\title{
Body Size and Body Volume Distribution in Two Sauropods from the Upper Jurassic of Tendaguru (Tanzania)
}

\author{
Hanns-Christian Gunga ${ }^{1}$, Karl Kirsch ${ }^{1}$, Jörn Rittweger ${ }^{1}$, Lothar Röcker ${ }^{1}$, Andrew Clarke ${ }^{2}$, \\ Jörg Albertz ${ }^{3}$, Albert Wiedemann ${ }^{3}$, Sascha Mokry ${ }^{3}$, Tim Suthau ${ }^{3}$, Aloys Wehr ${ }^{4}$, \\ Wolf-Dieter Heinrich ${ }^{5}$ \& Hans-Peter Schultze ${ }^{5}$
}

With 3 figures, 4 tables and 1 map

\begin{abstract}
Allometric equations are often based on the body mass of an animal because body mass determines many physiological functions. This should also hold for Brachiosaurus brancai and Dicraeosaurus hansemanni, two sauropods from the Upper Jurassic of Tendaguru/Tanzania (East Africa). Widely divergent estimates of body mass for the same specimen can be found in the literature for these two sauropods.

Therefore, in order to determine the exact body mass and volume distribution in these sauropods, classical three-dimensional stereophotogrammetry as well as a newly developed laser scanner technique were applied to the mounted skeletons of $B r a$ chiosaurus brancai and Dicraeosaurus hansemanni in the Museum für Naturkunde (Berlin, Germany). Thereafter, scaling equations were used to estimate the size of organ systems. In a second step it was tested whether the given data from photogrammetry could be brought in line with the results derived from the allometric equations. These findings are applied to possible ecological problems in the Upper Jurassic of Tendaguru/Tanzania.
\end{abstract}

Key words: Dinosauria, Sauropoda, palaeophysiology, evolutionary physiology, palaeoecology, body mass estimations, metabolism, nutrition, gait and posture.

\section{Zusammenfassung}

Der Körpermasse eines Organismus werden oft allometrische Funktionen zugrunde gelegt, da von ihr viele physiologische Funktionen entscheidend abhängen. Dies sollte auch für ausgestorbene Organismen wie Brachiosaurus brancai und Dicraeosaurus hansemanni, zwei Sauropoden aus dem oberen Jura von Tendaguru/Tanzania in Ostafrika gelten. Da zu beiden Sauropoden nur sehr unterschiedliche Massenabschätzungen vorliegen, wurden die Körpermassen und Volumina von Brachiosaurus brancai und Dicraeosaurus hansemanni mit Hilfe der klassischen Photogrammetrie sowie einem neuentwickelten Laserscannerverfahren neu bestimmt. Basierend auf den so gemessenen Körpermassendaten wurden anschließend einige wichtige funktionell-morphologische Größen für eine paläophysiologische Rekonstruktion dieser Sauropoden mit Hilfe der Allometrie berechnet. Die gewonnenen Ergebnisse sind u. a. wichtig für die Rekonstruktion eines Ökosystems im oberen Jura von Ostafrika.

Schlüsselwörter: Dinosauria, Sauropoda, Paläophysiologie, Evolutionäre Physiologie, Paläoökologie, Körpermassenabschätzungen, Stoffwechsel, Ernährung, Bewegung und Haltung.

\section{Introduction}

The German Tendaguru excavations in East Africa by the Friedrich Wilhelm Universität of Berlin from 1909 to 1913 were one of the most successful dinosaur excavations in the history of palaeontology (Janensch 1914a). The foremost achievements in terms of exhibiting the discoveries were the reconstruction of the Brachiosaurus brancai and Dicraeosaurus hansemanni skeletons, which are on display today in the $\mathrm{Mu}$ seum für Naturkunde in Berlin (Janensch 1935a, $1950 \mathrm{a}, \mathrm{b})$. For the viewer of the skeletons the body mass of both sauropods is most impressive.

\footnotetext{
${ }^{1}$ Institut für Physiologie, Universitätsklinikum Benjamin Franklin, Freie Universität Berlin, Arnimallee 22, D-14195 Berlin.

2 Vestibular-Forschungslabor, Universitätklinikum Benjamin Franklin, Freie Universität Berlin, Hindenburgdamm 30, D-12200 Berlin.

${ }^{3}$ Institut für Photogrammetrie und Kartographie, Technische Universität Berlin, Straße des 17, Juni 135, D-10623 Berlin.

${ }^{4}$ Institut für Navigation, Technische Universität Stuttgart, Geschwister-Scholl-Str. 24, D-70174 Stuttgart.

5 Institut für Palaeontologie, Museum für Naturkunde, Humboldt Universität, Invalidenstraße 43, D-10115 Berlin.

Received January 1999, accepted June 1999
} 
Comparative physiology has frequently shown that to make simple, quantitative, and reasonably accurate predictions of physiological parameters, the total body mass is of particular importance (Peters 1983, Withers 1992, Schmidt-Nielsen 1984, 1997). This should also hold for palaeophysiological reconstructions for Brachiosaurus brancai (skeleton SII) and Dicraeosaurus hansemanni (skeleton $\mathrm{m}$ ). Unfortunately, the body mass estimates found in the literature on these exhibited specimens are widely divergent, Brachiosaurus brancai 14.9-102 tons and Dicraeosaurus hansemanni 10-40 tons (Peczkis 1994). These estimates were based on projections from models or circumferential measurements of the humerus and femur (Colbert 1962, Lambert 1983, Anderson et al. 1985, Alexander 1989). The disadvantage of these methods lies principally in the use of models, where, depending on the enlargement factor, the most minor inaccuracies can lead to differences with a multiplication factor of 10 to 50 . When body mass is calculated by measuring the humerus and femur, it cannot be ruled out that the skeletal material examined actually comes from several different specimens. Furthermore there are still numerous gaps in the general comprehension of bone growth in dinosaurs (Reid 1984a, b; Sander 1999, in press). Moreover, extreme strain on the extremities, as occurs with the dynamic load of body mass walking and braking, plays a decisive role in bone growth. On this basis it is to be expected that the femur/ humerus circumference in various species, which normally also differ in their skeletal patterns of movement, i.e. load patterns, does not always correlate necessarily with the body mass determined purely statistically. In addition, it is known that with an otherwise equal circumference and cross-sectional surface, the inner structure of bones can vary, so that the corticalis, for example, can be thickened overproportionally in order to increase stability. Last not least, the envelope describing the range of masses for mammals falls far short of the likely mass of the sauropods.

For this reason our group took a few years ago a new approach to the estimation of body mass and body volume distributions (Gunga et al. 1995). Meanwhile, Henderson (1999) published very recently a similar method to estimate the masses and centers of mass of extinct animals by a 3-D mathematical slicing technique.

To register the body mass we applied classical photogrammetry and a newly developed laser scanner for large-scale objects. Points of refer- ence were mounted on the skeleton for the photogrammetry and a three-dimensional reconstruction was made with stereo projectors (Gunga et al. 1995, Wiedemann Wehr 1998, Wiedemann et al. 1999, in press). Then the dimensions of skeletons erected in the museum were determined by classical stereophotogrammetry either in the case of Brachiosaurus or scanned by a laser line by line in the case of Dicraeosaurus. On the basis of these photographic/electronic data the probable body contours of the skeletons were added (CAD technique) to calculate the body surface areas and masses. The reconstructions obtained in this way were cut up into larger parts and smaller elements and the volume and surface of each individual part was calculated from the usual geometric formulas according to Bronstein \& Semendjajew (1985), which we have described in detail earlier (Gunga et al. 1995). It was found that the body mass and body volume distributions indicate a completely different life-style for these two sauropods.

\section{Methods}

The study was performed on the specimens, i.e. Brachiosaurus brancai (skeleton II) and Dicraeosaurus hansemanni (skeleton $\mathrm{m}$ ), mounted and exhibited at the Museum of Natural History in Berlin (Germany). Preliminary results concerning body mass and volume distribution in $\mathrm{Bra}$ chiosaurus brancai were published earlier (Gunga et al. 1995). Therefore, a detailed description of the palaeontological setting and the classical photogrammetrical method applied on Brachiosaurus brancai is omitted here.

Briefly, the mounted specimens of Brachiosaurus and Dicraeosaurus were divided into elements (Figs 1,2), which were treated, according to their geometry, as spherical caps, cylinders or truncated cones (Brachiosaurus head 2 spherical caps and 1 cyclinder, other elements truncated cones; Dicraeosaurus head spherical caps, other elements truncated cones). The mathematical formulas used are given in Figs 1,2 . The different number of elements were compiled to parts I to XI in Brachiosaurus and I-VI in Dicraeosaurus.

\section{Palaeontological settings}

The skeletons of Brachiosaurus brancai (skeleton SII) and Dicraeosaurus hansemanni (skeleton m) are from the Upper Jurassic of Tendaguru/Tan- 
zania, East Africa (Map 1). The skeleton of $D i$ craeosaurus hansemanni was mounted in the $\mathrm{Mu}-$ seum für Naturkunde, Berlin, in 1930 (Janensch 1935a), that of Brachiosaurus brancai in 1937 (Janensch 1950b).

\section{Brachiosaurus brancai Janensch 1914}

The skeleton is a composite. The major part of the skeleton belongs to one single specimen of Brachiosaurus brancai recovered from the Middle Saurian Bed at Tendaguru Site S (Map 1). The tail originates from another individual of the same species and similar size found in the Upper
Saurian Bed at Tendaguru Site no (Map 1). In addition, skeletal remains of Brachiosaurus brancai excavated in different sites in the surroundings of the Tendaguru hill were used for the mounting, partly original and partly modelled. The presacral vertebral column (cervical, dorsal) and the skull have been replaced by plaster copies modelled from originals. The right shoulder blade, four ribs, and some bones of the left forefoot have been modelled in plaster according to counterparts on the other body side. Some missing elements were replaced by bones belonging to individuals of the same size, such as the right ilium, the right ischium, and left lower leg. Other

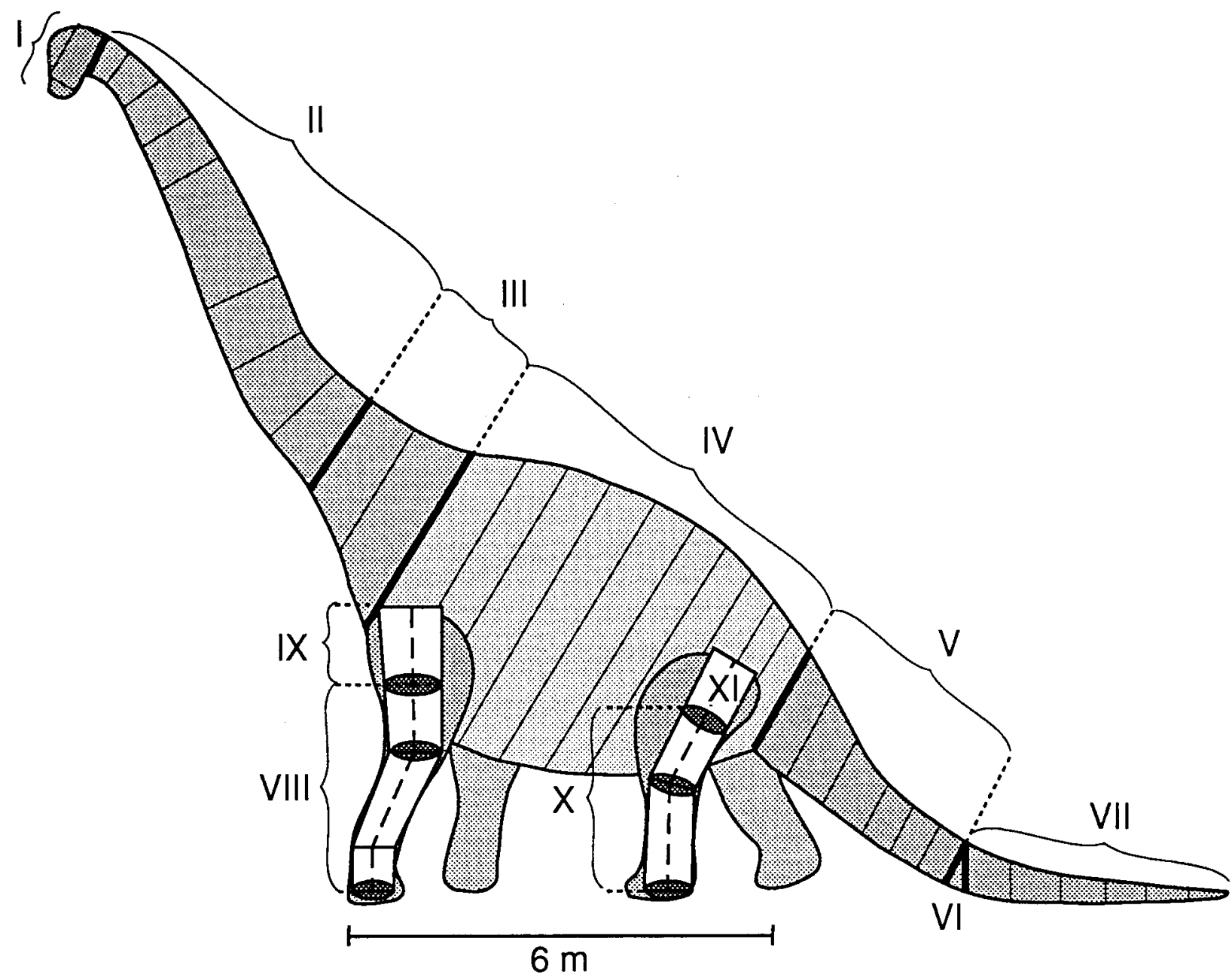

\section{Spherical Caps:}

$$
\begin{aligned}
& V=\frac{1}{3} \cdot \pi \cdot \mathrm{h}^{3} \cdot(3 \mathrm{r}-\mathrm{h}) \\
& S_{A}=2 \mathrm{r} \cdot \mathrm{h} \cdot \pi
\end{aligned}
$$

Cylinder:

$$
\begin{aligned}
& V=\pi \cdot \mathrm{r}^{2} \cdot \mathrm{h} \\
& S_{A}=2 \mathrm{r} \cdot \mathrm{h} \cdot \pi
\end{aligned}
$$

Truncated Cone:

$$
\begin{aligned}
& V=\frac{h \cdot \pi}{3}\left(r_{1}^{2}+r_{1} \cdot r_{2}+r_{2}{ }^{2}\right) \\
& S_{A}=\left(r_{1}+r_{2}\right) \cdot \pi \sqrt{\left(r_{1}-r_{2}\right)^{2}+h^{2}}
\end{aligned}
$$

Fig. 1. Lateral view of Brachiosaurus brancai showing the different parts taken for the volume and surface area calculations according to the formulas shown at the bottom of the figure 
missing items have been replaced by originals (e.g. left femur) or copies of bones from different-sized animals (i.e. sacrum, most hindfoot bones). At the very end of the tail four small pieces were added. Like the missing first caudal vertebra, most of the haemapophyses (chevrons) are plaster imitations (Janensch 1950b).

\section{Dicraeosaurus hansemanni Janensch 1914}

The skeleton of Dicraeosaurus hansemanni was recovered from the Middle Saurian Beds at Tendaguru site $\mathrm{m}$ (Map 1). The reconstructed skeleton consists mainly of bones from one single individual (specimen $\mathrm{m}$ ). Some missing bones were replaced by skeletal remains of other individuals of the same species and similar size which were recovered in the Middle Saurian Beds at Tendaguru Site dd (Map 1). Other missing parts of the skeleton have been replaced by plaster copies modelled after the original bones of Dicraeosaurus hansemanni or of $D$. sattleri. All original bones included in the mount are remarkably well preserved. Their basic shape has not been altered by taphonomic and diagenetic processes.

The skull has been reconstructed. It was modelled in plaster on the basis of skull bones from Site dd (Janensch 1935a). The most important parts of the vertebral column of specimen $\mathrm{m}$ were recovered in their proper anatomical posi- tion. The proatlas and atlas have not been found (Janensch 1929). The articulated part of the vertebral column comprises all vertebrae from cervical 2 to caudal 19. All of them were included in the skeletal reconstruction. With regard to the tail, only the anterior part was completely recovered (caudal 1 to 19). Except for three disarticulated caudal vertebrae, the posterior tail section (caudal 20 to 76) was apparently already missing when the skeleton was found. The missing items were either supplied by original caudal vertebrae from Tendaguru Site dd or replaced by plaster reconstructions.

The right coracoid and scapula come from Site dd. Their corresponding left counterparts as well as most of the cervical ribs, several left thoracic ribs, and the two sternal plates are plaster reconstructions. The right humerus included in the mount was recovered from the Middle Saurian Beds at locality $Q$ near Kijenere, about 9 $\mathrm{km}$ north of Tendaguru hill (Janensch 1925). The left humerus, both forearms, and the five-toed forefeet are also substitutes made of plaster.

As with the shoulder girdle and forelimbs, the pelvic girdle and the hindlimbs of skeleton $\mathrm{m}$ have not been completely recovered. The ilium, the pubis, parts of the ischium of the left body side were modelled in plaster according to their preserved counterparts from the right side. With the exception of the two thigh bones, the left tibia,

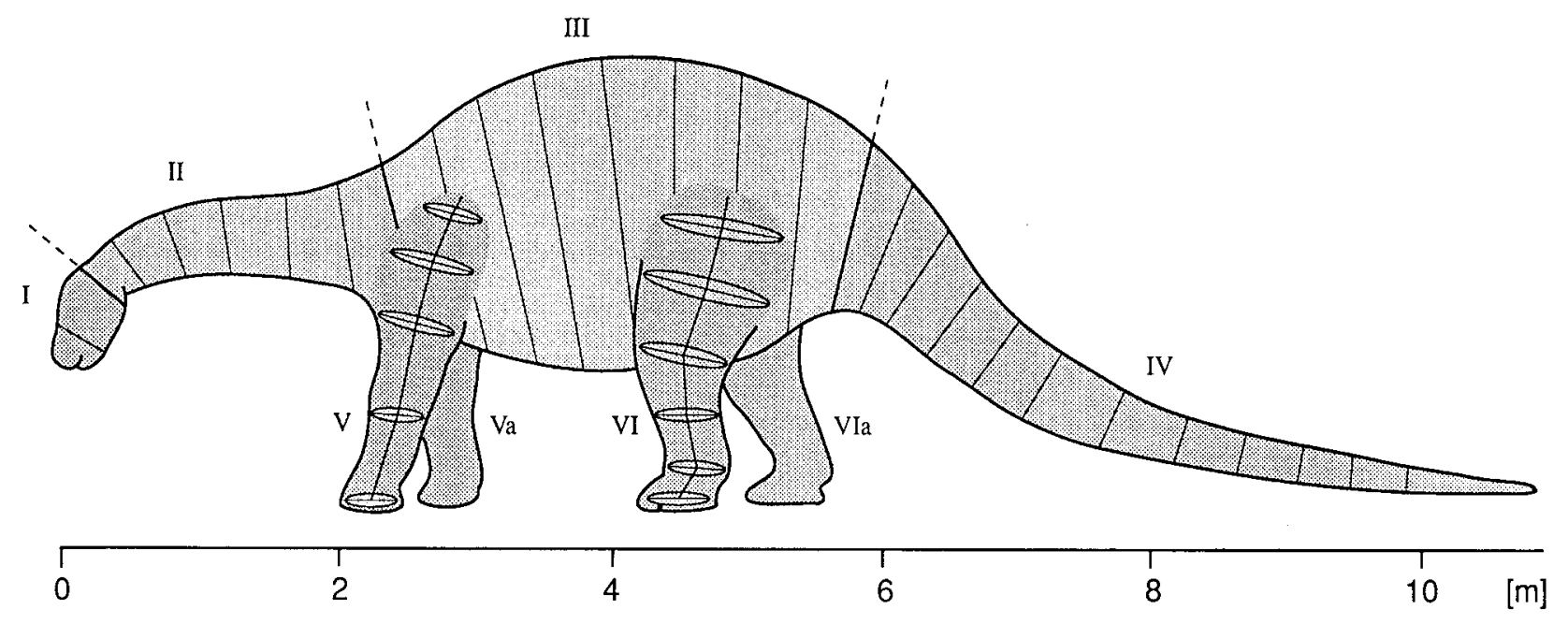

Truncated Cone:

$$
\begin{aligned}
& V=\frac{h \cdot \pi}{3}\left(r_{1}^{2}+r_{1} \cdot r_{2}+r_{2}^{2}\right) \\
& S_{A}=\left(r_{2}+r_{1}\right) \cdot \pi \sqrt{\left(r_{2}-r_{1}\right)^{2}+h^{2}}
\end{aligned}
$$

Fig. 2. Lateral view of Dicraeosaurus hansemanni showing the different parts taken for the volume and surface area calculations according to the formulas shown at the bottom of the figure 


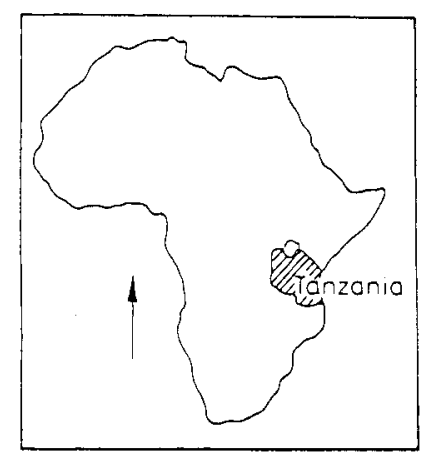

\section{Geographic location and geological structure of Tendaguru, Tanzania}
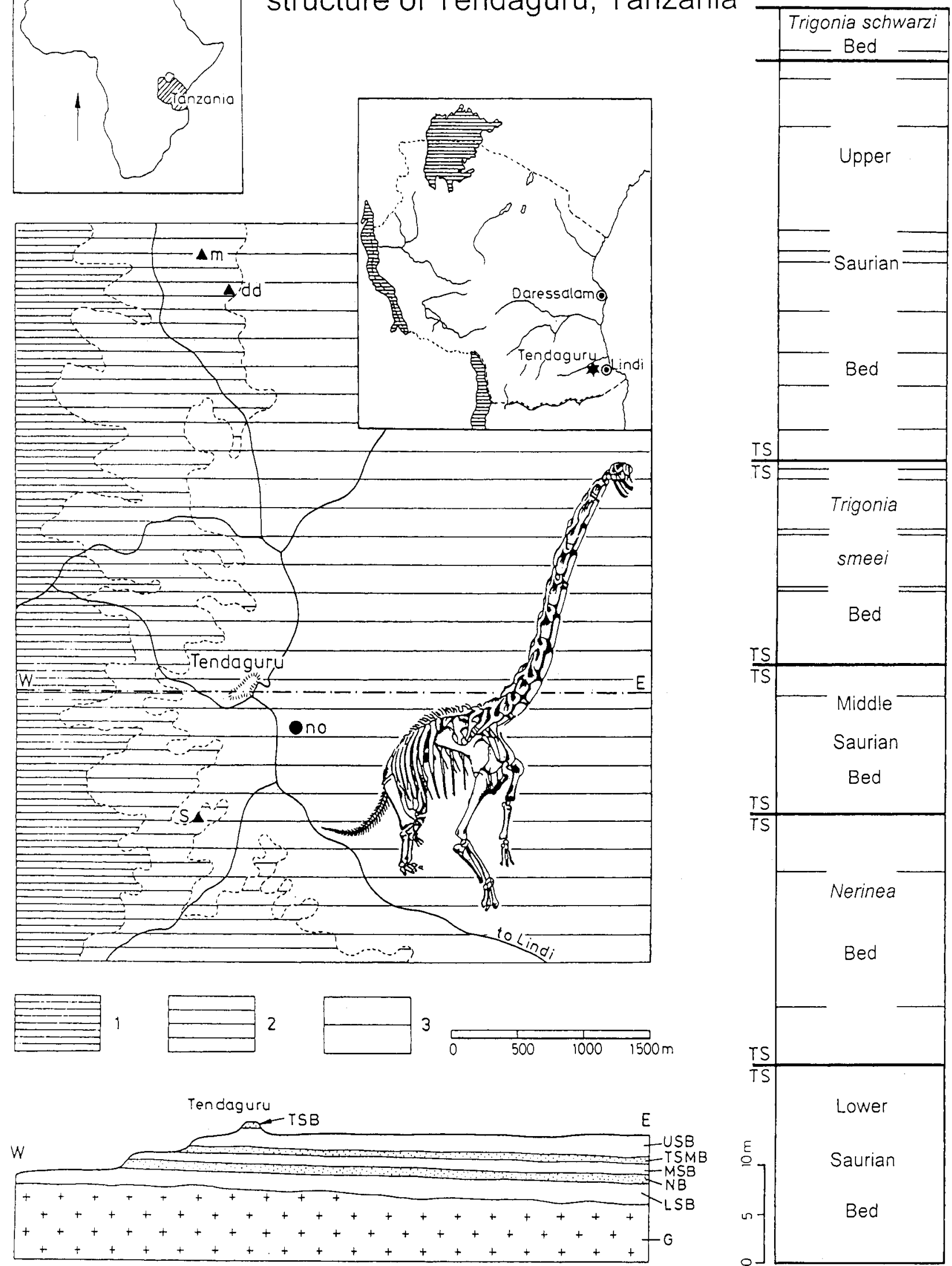

Map 1. Tendaguru area with geological sections and the location of the sites that produced the major parts of the mounted skeletons of Brachiosaurus brancai (sites S, no) and Dicraeosaurus hansemanni (sites m, dd). Data from Hennig (1914), Janensch (1914a, b, 1925). For details see Heinrich (1999). 1, Lower Saurian Bed; 2, Middle Saurian Bed; 3, Upper Saurian Bed; TSB, Trigonia schwarzi Bed; USB, Upper Saurian Bed; TSMB, Trigonia smeei Bed; MSB, Middle Saurian Bed; NB, Nerinea Bed; LSB, Lower Saurian Bed; G, gneiss; TS, Transitional Sands

$\triangle$ - Sites in the Middle Saurian Bed, - - Sites in the Upper Saurian Bed 
fibula, and astragulus, all hindlimb elements included in the mount are plaster reconstructions.

Earlier opinions suggested for sauropods an aquatic way of life (e.g., Janensch 1935a, b; Gregory 1951). Today, however, the concept of a land-living life-style for sauropods is widely accepted (e.g., Alexander 1989, McIntosh 1997).

\section{Results}

The body mass of Brachiosaurus was found to be $74.4 \mathrm{t}$ (Tab. 1) and that of Dicraeosaurus 12.8 t (Tab. 2).

The parts of Brachiosaurus (Tab. 1) show that the thorax occupies nearly $(74 \%)$ of the body volume, together with the limbs even $80 \%$ $(80.3 \%)$. The neck takes up $15 \%$, the head only
$0.20 \%$, nevertheless the tail with $4.4 \%$ cannot balance neck + head. This imbalance suggests a vertical, not a horizontal position of the neck (Christian \& Heinrich 1998).

In Dicraeosaurus, in contrast (Tab. 2), the head is 20 times larger compared to body volume than in Brachiosaurus; head + neck (6.4\%) are also closer to being balanced by the tail ( $8.5 \%$ body volume). Still, body and limbs make up over $80 \%(85.2 \%)$ of the total volume. We have here two dinosaurs with different volume distributions (Tab. 3): in Brachiosaurus the neck takes up a much larger percentage $(15 \%)$ of the total volume than in Dicraeosaurus $(6 \%)$. This conforms with the reconstruction of a vertical neck in Brachiosaurus and a horizontal neck in Dicraeosaurus, where it could berbalanced by the tail. The body of Dicraeosaurus is balanced on the strong hind limbs ( $8 \%$ of total volume).

Table 1

Parts, number of elements, parts of the body, body volumes and surface areas of Brachiosaurus brancai. I-XI, see Fig. 1 for identification of body parts; calculations of volume and surface area from formulas at the bottom of Figs 1,2 .

\begin{tabular}{lclcrr}
\hline Part & $\begin{array}{l}\text { Number } \\
\text { of elements }\end{array}$ & Part of the body & $\begin{array}{l}\text { Volume }(\mathrm{V}) \\
{\left[\mathrm{m}^{3}\right]}\end{array}$ & $\begin{array}{l}\text { Surface Area }\left(\mathrm{S}_{\mathrm{A}}\right) \\
{\left[\mathrm{m}^{2}\right]}\end{array}$ & $\begin{array}{l}\text { Surface Area }\left(\mathrm{S}_{\mathrm{A}}\right) \\
{[\%]}\end{array}$ \\
\hline I & 3 & Head & 0.14 & 1.5 & 1.1 \\
II & 8 & Neck & 5.04 & 19.5 & 14.0 \\
III & 2 & Neck & 6.16 & 11.3 & 8.2 \\
IV & 10 & Thorax & 55.12 & 66.7 & 48.0 \\
V & 6 & Tail & 2.81 & 10.2 & 7.3 \\
VI & 1 & Tail & 0.10 & 0.1 & 2.7 \\
VII & 6 & Tail & 0.37 & 3.8 & 4.4 \\
VIII & 3 & Forelimb right & 1.07 & 6.1 & 0.9 \\
IX & 1 & Forelimb right & 0.29 & 1.2 & 3.5 \\
X & 2 & Hindlimb right & 0.80 & 4.9 & 0.5 \\
XI & 1 & Hindlimb right & 0.18 & 0.7 & 4.4 \\
VIII & 3 & Forelimb left & 1.07 & 6.1 & 0.9 \\
IX & 1 & Forelimb left & 0.29 & 1.2 & 3.5 \\
X & 2 & Hindlimb left & 0.80 & 4.9 & 0.5 \\
XI & 1 & Hindlimb left & 0.18 & 0.7 & $\mathbf{1 0 0 . 0}$ \\
Total & $\mathbf{5 0}$ & & $\mathbf{7 4 . 4 2}$ & $\mathbf{1 3 8 . 9}$ &
\end{tabular}

Table 2

Parts, number of elements, parts of the body, body volumes and surface areas of Dicraeosaurus hansemanni. I-VIa, see Fig. 2 for identification of body parts; calculations of volume and surface area from formulas below table.

\begin{tabular}{llllcr}
\hline Part & $\begin{array}{l}\text { Number } \\
\text { of elements }\end{array}$ & Part of the body & $\begin{array}{l}\text { Volume }(\mathrm{V}) \\
{\left[\mathrm{m}^{3}\right]}\end{array}$ & $\begin{array}{l}\text { Surface Area }\left(\mathrm{S}_{\mathrm{A}}\right) \\
{\left[\mathrm{m}^{2}\right]}\end{array}$ & $\begin{array}{l}\text { Surface Area }\left(\mathrm{S}_{\mathrm{A}}\right) \\
{[\%]}\end{array}$ \\
\hline I & 2 & Head & 0.05 & 0.7 & 0.9 \\
II & 6 & Neck & 0.75 & 4.8 & 7.1 \\
III & 8 & Thorax & 9.38 & 20.2 & 55.9 \\
IV & 12 & Tail & 1.09 & 8.1 & 11.7 \\
V & 5 & Forelimb left & 0.26 & 2.6 & 2.8 \\
Va & 5 & Forelimb right & 0.26 & 2.6 & 9.4 \\
VI & 6 & Hindlimb left & 0.51 & 3.7 & 9.4 \\
VIa & 6 & Hindlimb right & 0.51 & 3.7 & $\mathbf{1 0 0 . 0}$ \\
Total & $\mathbf{5 0}$ & & $\mathbf{1 2 . 8 1}$ & $\mathbf{4 6 . 4}$ &
\end{tabular}


Table 3

Body volume distribution [\%] of Brachiosaurus brancai and Dicraeosaurus hansemanni.

\begin{tabular}{lcc}
\hline & $\begin{array}{l}\text { Brachiosaurus } \\
\text { brancai }\end{array}$ & $\begin{array}{l}\text { Dicraeosaurus } \\
\text { hansemanni }\end{array}$ \\
\hline Head & 0.2 & 0.4 \\
Neck & 15.1 & 5.9 \\
Thorax & 74.1 & 73.2 \\
Tail & 4.4 & 8.4 \\
Forelimbs & 3.6 & 4.1 \\
Hindlimbs & 2.6 & 8.0 \\
Total & $\mathbf{1 0 0 . 0}$ & $\mathbf{1 0 0 . 0}$
\end{tabular}

A comparison with extant long-necked animals (Fig. 3) like the giraffe demonstrates the required pumping power, i.e. blood pressure in the left heart ventricle, in Brachiosaurus. In a male giraffe, which can be $5.5 \mathrm{~m}$ in height and up to $2000 \mathrm{~kg}$ in body mass (Owen 1988), the heart is located $2.4 \mathrm{~m}$ above the ground and has to pump a distance of $2.8 \mathrm{~m}$ to the brain. Taking the present mounting as scale, this compares to $3.8 \mathrm{~m}$ above ground in Brachiosaurus and $7.9 \mathrm{~m}$ from heart to brain. With a vertical neck postion (Christian \& Heinrich 1998) the distance from heart to brain increases by about $1.5 \mathrm{~m}$. A more vertical position of the limbs also lifts the heart higher above the ground (Christian et al., this volume). The vertical heart-brain distance in humans is about $22 \%$, in the giraffe $56 \%$ of the total height, whereas in Brachiosaurus it is $66 \%$.

From the disparity in body masses a different set of physiological data are deduced (Tab. 4) using allometric formulas given for endotherms. $\mathrm{O}_{2}$ consumption of Brachiosaurus should be about 4 times that of Dicraeosaurus from which we calculated a basal metabolic rate of about $1.4 \times 10^{6}\left[\mathrm{~kJ} \cdot(24 \mathrm{~h})^{-1}\right]$ for Brachiosaurus and $0.4 \times 10^{6}\left[\mathrm{~kJ} \cdot(24 \mathrm{~h})^{-1}\right]$ for Dicraeosaurus. We assume that Brachiosaurus has six times the lung volume of Dicraeosaurus and a blood volume difference in the same range.

\section{Discussion}

First, we will comment on the methodology used. The main advantage of the photogrammetric procedure is that geometrical calculations can be easily made from each body part (Tabs 1 and 2). With a sufficient size and number of parts and elements, the error of measurement for the total body mass can be kept to a minimum (Wiedemann Wehr 1998, Wiedemann et al. 1999, in press). In contrast, when a measurement error appears with the humerus/femur circumference method, it results directly in a false calculation of the total mass. If a corresponding error is made when determining the volume of the lower

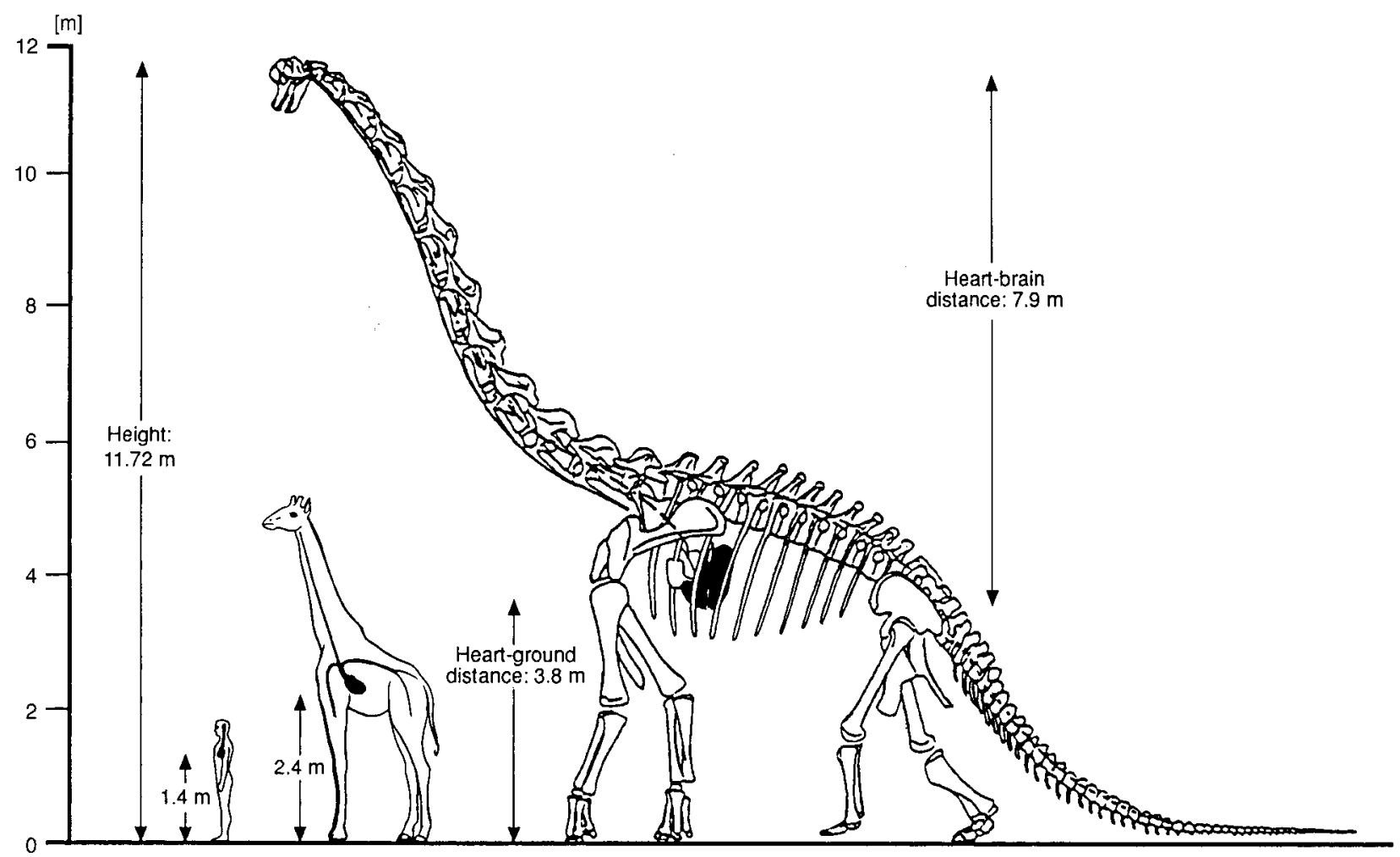

Fig. 3. A schematic view of the major hydrostatic distances acting on the heart and circulatory system in humans, giraffe and Brachiosaurus brancai 
extremities photogrammetrically, only the element measured is affected. Furthermore, the new data published by Sander (1999, in press) show that the internal bone structure changes during growth, so that bone circumference, for example, might not alter to the same extent as the internal structure. Very recently Henderson (1999) published a similar approach to our photogrammetrical method. In his calculations Henderson (1999) made use of various reconstruction drawings from one or more angles, which were digitalized two-dimensonally. Modelling of primitives was accomplished with a AutoCAD programme applied to truncated cones with ellipsoid sections and other geometric forms. The volume of the geometric primitives was calculated and the primitives of individual body parts and of the animal as a whole were complied. In comparison to our method in which only circular cone segments were used, resulting in a barrel-formed thorax, a strong point in Henderson's method is the improved mathematical modelling with elliptical sections of truncated cones. His approach also has the advantage that the measurements have been validated on living species. An advantage of our method is the three-dimensional registration of the original object as opposed to Henderson's approach of using solely two-dimensonal drawings. Another weakness in our opinion is Henderson's application of reconstruction drawings of questionable geometric quality, whereas in our case precise measurements of the skeleton were made and three-dimensional data applied.

Basic assumptions. Besides the new photogrammetric method to estimate body mass, which provides a scientific base for allometric computations, palaeoecological data are of value for the most realistic palaeophysiological reconstruction. Besides body mass, the physical conditions are of the utmost importance in a physiological reconstruction. With these kinds of observations and calculations it must be ensured that the basic physical conditions during the Late Jurassic, like atmospheric pressure, temperature, gravitation and length of the day, were comparable with those existing today in order to justify their applicability. Once these environmental factors affecting the organism are known, it is certainly possible to arrive at specific physiological statements on the probable function of individual systems of organs (Dunham et al. 1989). For this reason it should first be clarified what exactly is known about these basic conditions.
Atmospheric pressure and components. There are indications that dramatic changes in the atmosphere of the earth took place during the Paleozoic Age, but no serious alterations in the earth atmospheric oxygen pressure have occurred in the last 250 million years (Gilbert 1996, Gans et al. 1999) as indicated in particular by sedimentology, morphological and structural investigations from palaeobotany and from studies on preserved fossil egg-shells. The ultrastructure of the biological material shows a high similiarity to modern structures, especially with regard to the material used, the pore densities and the related diffusion properties according to Fick's Law. When we take a broader look at the oxygen content of the atmosphere in the course of geological history in general, we see dramatic changes in the atmosphere. But during the period in which the dinosaurs lived from 225 to 65 million years ago, the oxygen partial pressure at sea level was comparable to today's values (Gilbert 1996, Gans et al., 1999). This fact is decidedly significant in the efforts to reconstruct, as follows, the physiological capacity of the dinosaurs.

Temperature. According to measurements on belemnites, the palaeotemperature for mid-European waters was $20-27^{\circ} \mathrm{C}$ in Malm (Upper Jurassic) (Brinkmann 1977, Barron 1983, Sellwood et al. 1994). Therefore, it can be assumed that the global temperature on earth during the $\mathrm{Me}$ sozoic Age was approximately $3-4{ }^{\circ} \mathrm{C}$ higher than today. It remained above today's mean global temperatures until the Cenomanian/Turonian $(\mathrm{C} / \mathrm{T})$ boundary, which is characterized by the "oceanic anoxic event" and a global cooling of several degrees Celsius (Kuypers et al. 1999).

Gravitation. According to Dirac's theory published sixty years ago (cited after Economos 1981), we have to assume a change in the gravitational constant of about $1.0-1.5 \%$ during the Mesozoic age, a difference that seems to be negligible for the present calculations. Furthermore, cosmologists recently showed that the theory of Dirac might only have an impact during the first moments after the origin of the universe and did not play a role afterwards (personal communication Reeves, Seuil, France).

\section{Physiological data}

Body mass. The body mass of Brachiosaurus determined in our study as $74.4 \mathrm{t}$ is similar to 
the estimation of Colbert (1962), whereas those made by Béland \& Russel (1980), Anderson et al. (1985), Alexander (1989) and Janensch (1950b) are much lower. Our body mass estimation for Dicraeosaurus (12.8 t), in contrast, is in the lower range compared to those estimations given by Janensch (1950b), who assumed a body mass from $10-40 \mathrm{t}$.

Body volume distribution. The volume distributions indicate that nearly $90 \%$ of the mass in Brachiosaurus brancai is located in the neck and particularly in the thorax (Tab. 3). In Dicraeosaurus, in contrast, we see a small neck volume and a large body volume located in tail and hindlimbs. This suggests that Dicraeosaurus used his tail and hindlimbs to balance a horizontal neck posture during feeding. Moreover, it is interesting to note that its head volume in percentage of body mass was twice that of Brachiosaurus.

Nevertheless, it should be mentioned here that we are especially critical regarding the volume reconstruction of the Brachiosaurus neck with about $11 \mathrm{~m}^{3}$. This seems to be very high, indeed, and therefore studies using a laser scanner method are in progress to re-evaluate the volume of this part of the sauropod again. The results will be presented in a separate publication.

Body Surface Area. The body surface area for the unfolded skin is $138.9 \mathrm{~m}^{2}$ in Brachiosaurus and $46.4 \mathrm{~m}^{2}$ in Dicraeosaurus (Tabs. 1 and 2). If we look at the Brachiosaurus surface area distribution in percentages, it is interesting to note that the neck, limbs and tail sum up to $51 \%$ of the total skin (Tab. 1), in contrast to Dicraeosaurus with $43 \%$ (Tab. 2). These results are important in view of the basic metabolic rate and the heat exchange of large organisms with their environment (Haubold 1990, Carroll 1993). We will return to this point when discussing the respiration and metabolism, because the heat reflected from the ground does not reach the large surface area of Brachiosaurus as it does the surface area of the tail and large hindlimbs in $D i$ craeosaurus and probably other giant sauropods (Stevens \& Parrish 1999). Thermoregulatory mechanisms must take care of this problem.

Skeleton and Locomotion. The major constraints on large size in a terrestrial vertebrate are the limits placed on bone strength and muscle power (Briggs \& Crowther 1990, Weishampel et al. 1992). Animal skeletons are scaled allometrically with their body mass, so that the skeletons of large animals are more massive proportionally than those of small animals (Peters 1983, Schmidt-Nielsen 1997). If we assume that dinosaurs had a relatively high metabolic rate especially in their juvenile phase (see below) similar to that of endotherms, for which we have some new strong evidence (Barrick \& Showers 1994), we calculated a skeleton mass of $11.4 \mathrm{t}$ for Brachiosaurus and $1.7 \mathrm{t}$ for Dicraeosaurus (Tab. 4). Ricqlès (1980) has shown that the long bones in dinosaurs are characterized by a Haversian system, ressembling that in mammals, rather than showing the more characteristic reptilian structure. In addition, Sander (1999, in press) determined the histology of the long bones, primarily the humerus and femur, from four different sauropod genera from Tendaguru. He found that

\section{Table 4}

Physiological data of Brachiosaurus brancai and Dicraeosaurus hansemanni (Museum für Naturkunde, Berlin) calculated from equations of Bronstein \& Semendjajew (1985) and Schmidt-Nielsen (1984), and equating 1 l oxygen consumption during oxydative metabolism (at $0^{\circ} \mathrm{C}, 760 \mathrm{~mm} \mathrm{Hg}$ ) with $20.083 \mathrm{~kJ}$, according to Schmidt-Nielsen (1984).

\begin{tabular}{lllcc}
\hline & & & $\begin{array}{c}\text { Branchiosaurus } \\
\text { brancai }\end{array}$ & $\begin{array}{c}\text { Dicraeosaurus } \\
\text { hansemanni }\end{array}$ \\
\hline Body mass $(\mathrm{Mb})$ & {$[\mathrm{kg}]$} & & 74420 & 12800 \\
Body surface $(\mathrm{SA})$ & {$\left[\mathrm{m}^{2}\right]$} & & 138.9 & 46.4 \\
Skeleton & {$[\mathrm{kg}]$} & $\left(0.0608 \mathrm{Mb}^{1.083}\right)$ & 11480 & 1706 \\
$\mathrm{O}_{2}$ consumption & {$\left[\mathrm{l} \cdot \mathrm{h}^{-1}\right]$} & $\left(0.676 \mathrm{Mb}^{0.75}\right)$ & 3046 & 814 \\
$\mathrm{O}_{2}$ consumption & {$\left[\mathrm{l} \cdot \mathrm{h}^{-1} \cdot \mathrm{kg}^{-1}\right]$} & $\left(0.676 \mathrm{Mb}^{-0.25}\right)$ & 0.041 & 0.064 \\
Basal metabolic rate & {$\left[\mathrm{kJ} \cdot\left(24 \mathrm{~h}^{-1}\right]\right.$} & & 1468148 & 392342 \\
Lung volume & {$[\mathrm{l}]$} & $\left(0.063 \mathrm{Mb}^{1.02}\right)$ & 5866 & 974 \\
Tidal volume & {$[1]$} & $\left(0.0062 \mathrm{Mb}^{1.01}\right)$ & 516 & 4.6 \\
Respiration frequency & {$\left[\mathrm{min}^{-1}\right]$} & $\left(53.5 \mathrm{Mb}^{-0.26}\right)$ & 3 & 641 \\
Blood volume & {$[\mathrm{l}]$} & $\left(0.055 \mathrm{Mb}^{0.99}\right)$ & 3659 & 48 \\
Heart weight & {$[\mathrm{kg}]$} & $\left(0.0058 \mathrm{Mb}^{0.99}\right)$ & 386 & 23 \\
Heart rate & {$\left[\mathrm{min}^{-1}\right]$} & $\left(241 \mathrm{Mb}^{-0.25}\right)$ & 14.6 & 2
\end{tabular}


the long bone cortex consisted almost exclusively of fibrolammelar bone tissue, suggesting uniformly high growth rates in long bones, comparable to those in mammals and birds. With one exception - a Barosaurus from Tendaguru growth was uninterrupted as well. In all the taxa analysed, remodelling of the bone increases with age, and growth appears to slow down dramatically in individuals approaching their maximum size. According to the data published by Sander (1999), the Brachiosaurus brancai on exhibit at the Berlin Museum had not reached his ultimate size. We calculated the ultimate strength in compression of a similar Brachiosaurus femur. This femur had a length of $1.86 \mathrm{~m}$, a circumference of $0.8 \mathrm{~m}$ and showed a cross-sectional area of $158.5 \mathrm{~cm}^{2}$ at the middle part of the diaphysis. The cortex alone encompassed an area of $114.8 \mathrm{~cm}^{2}$. We found that the ultimate strength in compression for this femur lies around 180-190 t. Compared to a human femur showing a circumference/length ratio of $1: 5.6$, the ratio in the Brachiosaurus is only $1: 2.3$. Unfortunately, we have no comparable data up to now from $\mathrm{Di}$ craeosaurus.

What do we know about their locomotion? Fossil tracks of sauropods like Brachiosaurus show that these reptiles - completely different to recent modern reptiles - walked with their feet close to the midline beneath the body, similar to modern elephants (Norman 1991, Lambert 1993). Indeed, such a posture is the only practicable way for animals of this size to walk on dry land, because the force of gravity goes straight these to be the heavy limbs to the broad, rounded feet. We measured the circumferences of the fore- and hindfoot in Brachiosaurus and determined $2.20 \mathrm{~m}$ and $2.8 \mathrm{~m}$ respectively. Therefore, we assume a very slow locomotion due to its body mass, or also due to the limitations exerted by the thermoregulatory and circulatory systems.

Respiration and Metabolism. The oxygen from the environment travels via the respiratory tract to the alveoli and through their thin membranes reaches the blood. It is difficult to say whether the type of respiration that existed in Brachiosaurus was like that of a mammal or one more ressembling that of birds, who have socalled air sacks at their disposal (Perry 1989, 1992). Nevertheless, in Brachiosaurus the socalled "dead space" alone - that is the gas volume in the mouth, nose, larynx, and the trachea with the branching bronchial tubes which needs to be moved during respiration but which does not take part in the gas exchange - already amounts to a volume of about $20 \mathrm{l}$, compared to $150 \mathrm{ml}$ in humans. Again, assuming a metabolism similar to that of endotherms because of its fast growing rates (Sander 1999, this volume and Sander 1999, in press) and homiothermy probably faciliated due its large body mass (Spotila 1980, Hotton 1980) we applied allometric equations based on data from mammals to calculate presumable organ sizes and physiological parameter (Peters 1983, Withers 1992, Schmidt-Nielsen $1984,1997)$. Its lung volume must have been on the scale of 6000 litres and its tidal volume 5201 , with an estimated respiratory rate of around 3 breaths per minute (Tab. 4). From a gravitational point of view a mammalian lung type could create serious problems. The huge Brachiosaurus lung causes hydrostatic pressure differences between its top and bottom, amounting to possibly more than $60 \mathrm{~mm} \mathrm{Hg}$, which would seriously affect the capillary pressures in the lung.

With a body mass of $74 \mathrm{t}$, it follows that the Brachiosaurus oxygen consumption at rest was about 501 per min compared to 0.3 litres in humans. Furthermore, we can assume a basal metabolic rate of approximately $1.47 \cdot 10^{6} \mathrm{~kJ} \cdot\left(24 \mathrm{~h}^{-1}\right)$ (Tab. 4). The estimated amount of food ingested would probably have been less than $1 \%$ of the total body weight or approximately $350 \mathrm{~kg}$. In all our calculations we assumed that approximately $70 \%$ of the plant intake is water and $30 \%$ represents the dry mass, of which $50 \%$ was actually absorbed by the gastro-intestinal tract, as is known from living megaherbivores (Owen-Smith 1988). Furthermore, with regards to the posture of its neck and longer forelimbs, it appears that this dinosaur must have been an extremely specialized high browser; the neck was positioned even more vertically than in the restored position (Christian \& Heinrich 1998).

Heart and Circulation. The capacity of the cardio-circulatory system of $B$. brancai seems to be a critical point per se, as was first described by Hohnke (1973). Our measurements show that the vertical distance from the vault of the cranium to the ground is $11.7 \mathrm{~m}$ (Fig. 3) without a completely erect neck and front limbs (see Christian et al., this volume). We calculated a vertical heart-ground distance of $3.80 \mathrm{~m}$ and a heartbrain distance of $8.00 \mathrm{~m}$ in the mounted skeleton. The carotids were about $9.80 \mathrm{~m}$ long. These anatomical-morphological conditions place very tight restrictions on the level of physical exercise. 
The blood volume was about 36001 , the heart weight at least $386 \mathrm{~kg}$ with a stroke volume of approximately $17.4 \mathrm{l}$, and a heart frequency of $14.6 \mathrm{~min}^{-1}$ (Tab. 4). From our point of view this reconstruction of the cardiovascular system in Brachiosaurus with a completely four-chamber heart is the only plausible solution at present. The hypothesis recently published by Choy \& Altman (1992) showing several muscle pumps located in the vascular system of the long sauropod neck should be rejected in our opinion. The chronological and volumetric coordination of several hearts with this type of pump mechanism would present extremely difficult physiological problems. Assuming a classical four-chambered heart, on the other hand, the left ventricle would have had to generate a pressure of about 600 to $750 \mathrm{~mm} \mathrm{Hg}$ to surmount the enormous hydrostatic blood column of about 8.0 metres to reach the Brachiosaurus brain (Fig. 3). Such a cardiac pressure function is unknown in today's animal world. But in giraffes, 3-4 m tall, blood pressures from 260 to $360 \mathrm{~mm} \mathrm{Hg}$ have been measured (Hargens et al. 1987). Nonetheless, the giraffe's cerebral blood vessels show a pressure of $100 \mathrm{~mm} \mathrm{Hg}$ during changing neck positions. This is achieved by the intervention of a rete mirabile. We might assume that Brachiosaurus, especially, would have had such a structure as well in the head area.

The veins are a part of the low pressure system and contain by far the greatest portion of the total blood volume, which is usually between 5 and $10 \%$ of the body mass - leading in Brachiosaurus to a blood volume of about 3,659 litres (Tab. 4). $80 \%$, or 3000 litres, were probably located in the veins, the right heart and the vessels of the pulmonary circulation. Because of the hydrostatic load at the level of the extremities, Brachiosaurus must have been equipped with an ingenious "oedema prevention mechanism". Venous valves, muscular venous pumps, extremely strong connective tissue and a thickened basal membrane, as seen in the extremities of giraffes and gazelles (Hargens et al. 1987, Withers 1992), could have developed in Brachiosaurus.

Finally, looking at the different organ sizes of Brachiosaurus and Dicraeosaurus the thoracicabdominal cavity in both dinosaurs seems to be large enough to carry these organs and a gastrointestinal tract as well which is, surprising enough, in some megaherbivores, for example the African elephant, relatively small (Owen 1988). It can be concluded from these studies that sauropods like Brachiosaurus were highly specialized with regards to their metabolism, circulation and temperature regulation. Even the most minor changes in their environment involving climate, food or fluid intake would have had catastrophic consequences for the survival of such huge organisms.

\section{Acknowledgements}

This research was supported by the Deutsche Forschungsgemeinschaft (Grant Gu 414-2-1).

\section{References}

Alexander, R. M. 1989. Dynamics of dinosaurs and other extinct giants. 167 pp., Columbia University Press, New York.

Anderson, J. F., Hall-Martin, A. \& Russell, D. A. 1985. Long-bone circumference and weight in mammals, birds, and dinosaurs. - Journal of Zoology 207: 53-61.

Barron, E. J. 1983. A warm, equable Cretaceous: The nature of the problem. - Earth Science Review 19: 305-338.

Brinkmann, R. 1977. Historische Geologie, II. Band. 400 pp., Ferdinand Enke Verlag, Stuttgart.

Barrick, R. E. \& Showers, W. J. 1994. Thermophysiology of Tyrannosaurus rex: Evidence from oxygen isotopes. Science 265: 222-224.

Béland, P. \& Russel, D. A. 1980. Dinosaur metabolism and predator/prey ratios in the fossil record. $\ln \mathrm{R}$. D. K. Thomas \& Olson E. C. (eds.). A cold look at the warmblooded dinosaurs. AAAS Selected Symposium 28: 85-102.

Briggs, D. E. G. \& Crowther, P. R. (eds.) 1990. Palaeobiology. A Synthesis. 583 pp., Blackwell Science Ltd., Oxford, London, Edinburgh.

Bronstein, I. N. \& Semendjajew, K. A. 1985. Taschenbuch der Mathematik. 840 pp., Deutsch, Thun.

Carroll, R. L. 1993. Paläontologie und Evolution der Wirbeltiere. 684 pp., Georg Thieme Verlag, Stuttgart, New York.

Choy, D. S. \& Altman, P. 1992. The cardiovascular system of barosaurus: an educated guess. - Lancet 340: 534-536.

Christian, A. \& Heinrich, W.-D. 1998. The neck posture of Brachiosaurus brancai. - Mitteilungen des Museums für Naturkunde Berlin, Geowissenschaftliche Reihe 1: 73-80.

Christian, A., Heinrich, W.-D. \& Golder, W. 1999. Posture and mechanics of the forelimbs of Brachiosaurus brancai. Geowissenschaftliche Reihe 2: 63-73.

Colbert, E. H. 1962. The weights of dinosaurs. - American Museum Novitates 2076: 1-16.

Dunham, A. E., Overall, K. L., Porter, W. P. \& Forster, C. A. 1989. Implications of ecological energetics and biophysical and developmental constraints for life-history variation in dinosaurs. - Geological Society of America, Special Paper 238: 1-19.

Economos, A. C. 1981. The largest land mammal. - Journal of Theoretical Biology 89: 211-215.

Gans, C., Dudley, R., Aguilar, N. M. \& Graham, J. B. 1999. Late Palaeozoic atmospheres and biotic evolution. - Historical biology 13: 199-219.

Gilbert, D. L. 1996. Evolutionary aspects of atmospheric oxygen and organisms. In M. J. Fregly \& Blatteis C. M. (eds.) Handbook of environmental physiology, Volume II: 1059-1094, Oxford University Press, New York, Oxford.

Gregory, W. K. 1951. Evolution emerging. A survey of changing patterns from primeval life to man. Volume 1 , 739 pp, volume 2, 1013 pp., Macmillian Company, New York. 
Gunga, H.-C., Kirsch, K. A., Baartz, F., Röcker, L., Heinrich, W.-D., Lisowski, W., Wiedemann, A. \& Albertz, J. 1995. New data on the Dimensions of Brachiosaurus brancal and their physiological implications. - Naturwissenschaften 82(4): 189-192.

Hargens, A. R., Millard, R. W., Petterson, K. \& Johansen, K. 1987. Gravitational haemodynamics and oedema prevention in the giraffe. - Nature 329: 59-60.

Haubold, H. 1990. Die Dinosaurier. System, Evolution, Paläobiologie. (4. Aufl.). 248 pp., A. Ziemsen Verlag, Wittenberg.

Heinrich, W.-D. 1999. The taphonomy of dinosaurs from the Upper Jurassic of Tendaguru, Tanzania (East Africa), based on field sketches of the German Tendaguru expedition (1909-1913). - Mitteilungen aus dem Museum für Naturkunde Berlin, Geowissenschaftliche Reihe 2: $25-61$.

Henderson, D. M. 1999. Estimating the masses and centers of mass of extinct animals by mathematical slicing. Palaeobiology 25(1): 88-106.

Hennig, E. 1914. Beiträge zur Geologie und Stratigraphie Deutsch-Ostafrikas. I. Geologisch-stratigraphische Beobachtungen im Küstengebiet des südlichen Deutsch-Ostafrika. II. Geologisch-stratigraphische Beobachtungen im Gebiete der Jura-Ablagerungen an der Deutsch-Ostafrikanischen Zentralbahn. - Archiv für Biontologie 3(3): $1-72$.

Hohnke, L. A. 1973. Haemodynamics in the Sauropoda. Nature 244: 309-310

Hotton, N. 1980. An alternative to dinosaur endothermy. The happy wanderers. In R. D. K. Thomas \& Olson E. C. (eds.), A cold look at the warm-blooded dinosaurs. AAAS Selected Symposium 28: 311-350.

Janensch, W. 1914a. Bericht über den Verlauf der Tendaguru-Expedition. - Archiv für Biontologie 3(1): 17-58.

- 1914b. Die Gliederung der Tendaguru-Schichten im Tendaguru-Gebiet und die Entstehung der Saurier-Lagerstätten. - Archiv für Biontologie 3(3): 227-261.

- 1925. Die Grabungsstellen der Tendaguru-Gegend. Palaeontographica, Supplement VII, 1 Reihe, Teil 1, Lieferung 1: XVII-XIX.

- 1929. Die Wirbelsäule der Gattung Dicraeosaurus. Palaeontographica, Suppl. 7(1, Teil 2): 35-133.

- 1935a. Ein aufgestelltes Skelett von Dicraeosaurus hansemanni. - Palaeontographica, Suppl. 7(1, Teil 2): 299-308.

- 1935b. Die Schädel der Sauropoden Brachiosaurus, Barosaurus und Dicraeosaurus aus den Tendaguru-Schichten Deutsch-Ostafrikas. - Palaeontographica, Suppl. 7 (2, Teil 2): 145-297.

- 1950a. Die Wirbelsäule von Brachiosaurus brancai. Palaeontographica, Suppl. 7(1, Teil 3): 27-92.

- 1950b. Die Skelettrekonstruktion von Brachiosaurus brancai. - Palaeontographica, Suppl. 7(1, Teil 3): 95-102.

Kuypers, M. M. M., Pancost, R. D. \& Damsté, J. S. S. 1999. A large and abrupt fall in atmospheric $\mathrm{CO} 2$ concentration during Cretaceous times. - Nature 399: 342-345.

Lambert, D. 1983. A field guide to dinosaurs. 256 pp., Avon, New York.

- 1993. The Ultimate Dinosaur Book. 192 pp., Dorling Kindersley Inc., London.

McIntosh, J. S. 1997. Sauropoda. In Currie, P. J. \& Padian, K. (eds.), Encyclopedia of dinosaurs. 654-658, Academic Press, San Diego, London, Boston etc.
Norman, D. 1991. Dinosaurier. 192 pp., C. Bertelsmann Verlag, München.

Owen-Smith, R. N. 1988. Megaherbivores. The influence of very large body size on ecology. 269 pp., Cambridge University Press, Cambridge.

Peczkis, J. 1994. Implications of body-mass estimates for dinosaurs. - Journal of Vertebrate Paleontology 14: 520-533.

Perry, S. F. 1989. Mainstreams in the evolution of vertebrate respiratory structures. - Form and Function in Birds 4: $1-67$.

- 1992. Gas exchange strategies in reptiles and the origin of the avian lung. In Wood, S. C., Weber, R. E., Hargens, A. R. \& Millard, R. W. (eds.), Physiological Adaptations in Vertebrates. 149-167, Marcel Dekker Inc., New York, Basel, Hong Kong.

Peters, R. H. 1983. The ecological implications of body size. 329 pp., Cambridge University Press, Cambridge.

Reid, R. E. H. 1984a. Primary bone and dinosaurian physiology. - Geological Magazine 121: 589-598.

- 1984b. The histology of dinosaurian bone, and its possible bearing on Dinosaurian physiology. - Symposium of the Zoological Society London 52: 629-663.

Ricqlès, A. J. de 1980. Tissue structures of dinosaur bone. Functional significance and possible relation to dinosaur physiology. In R. D. K. Thomas \& Olson E. C. (eds.), A cold look at the warm-blooded dinosaurs. AAAS Selected Symposium 28: 103-139.

Sander, P. M. 1999: Life history of the Tendaguru sauropods as deduced from long bone histology. - Mitteilungen aus dem Museum für Naturkunde Berlin, Geowissenschaftliche Reihe 2: 103-112.

- (in press) Long bone histology of the Tendaguru sauropods: Implication for growth and biology. - Palaeobio$\log y$

Schmidt-Nielsen, K. 1984. Scaling: Why is animal size so important? 241 pp., Cambridge University Press, Cambridge.

- 1997. Animal Physiology. 607 pp., Cambridge University Press, Cambridge.

Sellwood, B. W., Price, G. D. \& Valdes, P. J. 1994. Cooler estimates of Cretaceous temperatures. - Nature 370: $453-455$

Spotila, J. S. 1980. Constraints of body size and environment on the temperature regulation of dinosaurs. In R. D. K. Thomas \& Olson E. C. (eds.), A cold look at the warmblooded dinosaurs. AAAS Selected Symposium 28: $233-252$.

Stevens, K. A. \& Parrish, J. M. 1999. Neck posture and feeding habits of two Jurassic sauropod dinosaurs. - Science 284: $798-800$.

Weishampel, D. B., Dodson, P. \& Osmólska, H. (eds.) 1992. The Dinosauria. 733 pp., University of California Press, Berkeley, Los Angeles.

Wiedemann, A. \& Wehr, A. 1998. Vermessung von Dinosaurierskeletten mit Stereophotogrammetrie und Laserscanner. - Publikationen der Deutschen Gesellschaft für Photogrammetrie und Fernerkundung 6: 301-308.

Wiedemann, A., Suthau, T. \& Albertz, J. 1999. Survey of Dinosaur Skeletons. - Mitteilungen des Museums für Naturkunde Berlin, Geowissenschaftliche Reihe 2: 113-119.

Withers, P. C. 1992. Comparative animal physiology. 949 pp. Saunders College Publishing, Fort Worth. 